\title{
NAHDLATUL ULAMA: \\ MENCARI KOMPROMI ISLAM DAN KEBANGSAAN
}

\author{
Oleh: Saefur Rochmat
}

(FISE - UNY)

\begin{abstract}
Abstrak:
Indonesia merupakan salah satu negara yang mayoritas penduduknya beragama Islam, bahkan jumlah Muslimnya terbesar di dunia. Sebagaimana di negara-negara yang semisal, Indonesia mengalami kendala dalam masalah hubungan Islam dan negara (kebangsaan). Sebagian Muslim beranggapan Islam sebagai agama yang komprehensif jelas-jelas mengatur masalah negara ini. Mereka yakin kalau Nabi Muhammad SAW. sebagai pembawa risalah Islam juga memiliki visi untuk mendirikan negara. Kekhalifahan dipandangnya sebagai sistem pemerintahan negara Islam. Pandangan ini sudah mendapat kritik tajam pada abad ke-20.

$N U$ berhasil mengembangkan suatu pemikiran agama yang dikemas dalam kerangka negara bangsa. Negara bangsa bukan suatu yang tabu dalam Islam, karena kekhalifahan adalah hasil ijtihad para sahabat Nabi yang tidak tabu terhadap kritik. Yang dipentingkan Islam bukan bentuk negara, tapi suatu negara sebagai suatu alat untuk menjamin adanya tertib sosial, suatu prasyarat bagi tegaknya agama. Tidak heran bila NU berhasil mengembangkan suatu pemikiran yang mendukung eksistensi Pancasila dalam kapasitasnya sebagai dasar negara Indonesia yang sebenar-benarnya. Dan melalui Muktamar 1984, NU mempelopori mencabut Islam sebagai asas organisasi dan menggantinya dengan Pancasila.

Pendirian NU tersebut memiliki dasar yang kokoh pada ajaranajaran agama yang dianutnya dan dirumuskan dalam Ahlus Sunnah wal Jama'ah (Aswaja). Aswaja adalah suatu sistem atau cara yang kembali pada QS al-Hajj 54 bahwa kebenaran harus dicari dengan nalar (logika) dan Abu Hanifah merupakan orang yang merintis cara berpikir Aswaja itu. Aswaja bukan suatu madzhab, tetapi manhaj alfikr (cara berpikir, yakni suatu cara berpikir meletakkan aspek tawasuth, tasamuh, mengutamakan cara persuasif dan menghindari kekerasan sebagai dasar pijakan dalam memahami ajaran agama dalam rangka mencari jalan tengah, sebagai suatu bentuk kompromi antara idealita dengan kondisi empiris.
\end{abstract}




\section{Pendahuluan}

Seringkali dialektika tidak segera mengarah pada hubungan dialogis berupa kompromi, tapi sering ditandai gejala sekresi (pemisahan diri atau perpecahan) yang saling menegasikan. Selanjutnya sekresi mengarah pada keadaan status quo dan akhirnya lahirlah co-eksistensi di antara keduanya. Tahap selanjutnya baru terjadi dialog konstruktif. Memang kita membutuhkan waktu begitu lama untuk terjadinya dialog yang konstruktif itu, karena kita belum membiasakan diri dengan budaya demokrasi.

Kita merasa prihatin menyaksikan perkembangan sejarah Islam di Indonesia yang sering diwarnai gejala sekresi (pemisahan diri) atau perpecahan. Pertama kali lahir Sarekat Dagang Islam (SDI) yang didirikan oleh H. Samanhudi dan dalam perkembangannya menjadi Sarekat Islam (SI) di bawah HOS. Cokroaminoto. Dalam SI berkembang berbagai macam pemahaman tentang Islam, dan SI tidak dapat mengambil keputusan yang strategis untuk mengakomodasikan konsep-konsep Islam dengan konsep-konsep komunisme, sehingga berakibat perpecahan ke dalam SI Putih dan SI Merah.

Sering terjadinya perpecahan dalam bidang politik menjadi pemicu bagi KH. Ahmad Dahlan untuk mendirikan ormas keagamaan Muhammadiyah pada tahun 1912. KH Ahmad Dahlan berjuang melalui jalur pendidikan seperti yang dilakukan Muhammad Abduh, namun dia menempuh cara yang modern dengan mendirikan organisasi. Sebagai salah satu gerakan Islam yang terpengaruh modernisme, Muhammadiyah bertekad untuk membuka pintu ijtihad.

Akibatnya Muhammadiyah tidak dapat melangkah mulus, terutama di daerah pedesaan dan akhirnya mendapat rival dari kalangan pesantren yang mendirikan Nahdlatul Ulama (NU).

\section{Latar Belakang Berdirinya NU}

1. Menurut Deliar Noer: Organisasi ini didirikan di Surabaya tanggal 31 Januari 1926 sebagai usaha menahan perkembangan paham pembaharu dalam Islam di tanah air, serta usaha mempertahankan ajaran tradisional dan mazhab di tanah suci yang baru dikuasai golongan Wahabi di bawah Raja Abdul Aziz bin Sa'ud (Deliar Noer, 2000: 85).

2. Menurut Ali Haidar: Kalau kemudian konflik keagamaan dengan aliran baru itu dianggap sebagai bukti, hal itu terjadi karena NU lahir di sekitar peristiwa yang terjadi itu. Akan tetapi kita tidak 
bisa menutup fakta lain adanya pergulatan panjang yang terjadi sebelumnya, sejak awal tahun belasan, ketika sejumlah ulama muda pesantren mengembangkan kegiatan sosial kemasyarakatan dengan obsesi mengenai hari depan umat Islam Indonesia. Mereka inilah yang kemudian membidani kelahiran NU. Hal ini juga terbukti dari visi keagamaan NU yang sampai sekarang tetap berkembang (M. Ali Haidar, 1998: 11).

3. Menurut Martin van Bruinessen : Kelahiran NU pada tahun 1926 tidak hanya sebagai reaksi atas serangan Islam reformis secara nasional, tetapi juga merupakan respon atas bangkitnya kekuasaan Islam puritan Wahabi di Mekkah (Imam Baehaqi, 2000: ix).

4. Menurut Ketua PBNU, Sholahuddin Wahid: NU didirikan tahun 1926 Masehi di Jombang. Didirikan oleh sejumlah Ulama yang pada waktu itu ada kaitannya dengan Komite Hijaz. Di Saudi Arabia, ada gerakan dari kaum Wahabi yang dikhawatirkan akan merusak beberapa peninggalan termasuk makam Rasulullah SAW. Kemudian ditindaklanjuti dengan suatu kegiatan yang akhirnya memunculkan NU ini, untuk mempertahankan Ahlus Sunnah wal Jama'ah (Sholahuddin Wahid, 2003).

Setelah kita melihat keempat pendapat tersebut di atas, dapat disimpulkan bahwa tujuan didirikannya NU adalah untuk mensosialisasikan paham Ahlus Sunnah wal Jama'ah. Perlu ditegaskan di sini bahwa berdirinya NU bukanlah antitesa bagi organisasi Islam yang telah ada tetapi sangat diharapkan untuk menjadi "Mitra Jihad" menuju kemajuan Indonesia. Dengan demikian, kelahiran NU merupakan respon langsung atas bangkitnya kekuasan Islam puritan Wahabi di Mekkah.

Komite Khilafah yang dibentuk untuk mengirimkan wakil Indonesia ke Mekkah dianggap tidak dapat mewakili suara pihak pesantren, sehingga para ulama membentuk Komite Hijaz. Tujuan dibentuknya Komite Hijaz dalam sidang tanggal 31 Januari 1926 adalah untuk mengirimkan wakil ke Mekkah. Dalam sidang itu didirikan NU yang akan memberi mandat pada Komite Hijaz ini, ditetapkan para wakil yang akan dikirim ke Mekkah; dan kemudian dibubarkannya Komite Hijaz ini (M. Ali Haidar, 1998: 58-59). 


\section{NU dan Ahlus Sunnah wal Jama'ah}

Dalam Anggaran Dasar NU dicantumkan bahwa NU menganut madzab Ahlus Sunnah wal Jama'ah. Menurut M. Ali Haidar (1998: 67-68) sunnah mempunyai dua pengertian:

1. Sunnah berarti metoda (tariqah), yaitu mengikuti metoda para sahabat dan tabi'in serta salaf dalam memahami ayat-ayat mutasyabihat dengan menyerahkan sepenuhnya pengertian ayat tersebut kepada Allah sendiri, tidak mereka-reka menurut daya nalar manusia semata-mata.

2. Sunnah berarti hadits Nabi Muhammad yaitu meyakini kebenaran hadits sahih sebagai dasar keagamaan.

Hal tersebut menunjukkan bahwa dasar keagamaan yang dianut bersumber kepada al-Qur'an dan Sunnah Nabi dan sunnah para sahabat atau lazim dengan ungkapan ijma' sahabat, yaitu tradisi yang telah melembaga dalam kehidupan sosial keagamaan para sahabat.

Dalam Qanun Asasi yang ditulis Hadlratus Syaikh KHM. Hasyim Asy'ari diberikan batasan yang praktis tentang Ahlus Sunnah wal Jama'ah (Aswaja) (Said Aqiel Siradj, 2000: 3), yaitu madzhab yang:

1. Dalam akidah, mengikuti salah satu dari Imam Abu Hasan alAsy'ari dan Imam Abu Mansur al-Maturidi.

2. Dalam 'ubudiyah (praktek beribadah) mengikuti salah satu imam empat: Abu Hanifah, Malik bin Anas, Muhammad al-Syafi'i da Ahmad bin Hambal.

3. Dan dalam ber-tashawuf mengikuti salah satu dua imam: Abu Qasim al-Junaidi al-Baghdadi dan Abu Hamid Muhammad alGhazali.

Sekarang ada usaha untuk merevitalisasi Aswaja dan untuk keperluan tersebut dilakukan usaha untuk mendudukkan Aswaja secara tepat. Selanjutnya ditandaskan bahwa Aswaja bukanlah madzhab, tetapi manhaj al-fikr (cara berpikir) tertentu yang digariskan oleh para Sahabat dan para muridnya generasi Tabi'in yang memiliki intelektualitas tinggi dan relatif netral dalam mensikapi situasi politik ketika itu.

Pada masa akhir Khulafaur Rasyidin pecahlah perang antara Khalifah Ali dengan Gubernur Muawiyah. Ini dikenal dengan bencana besar (fitnah kubra) karena sesama Muslim berperang. Kemudian muncullah kelompok baru yang yang memposisikan dirinya di tengahtengah. Dialah Sa'id bin Abi Waqas, yang tidak mau terlibat dalam masalah-masalah politik, dan memilih 'uzlah membuat kelompok 
sendiri. Termasuk dalam kelompok ini adalah Ibnu Umar (Said Aqiel Siradj, 2000: 16).

Dalam situasi politik yang tidak menentu ada beberapa orang dari generasi Tabi'in yang bisa berpikir jernih dan netral, seperti Sufyan al-Tsauri bin Uyainah, Imam Abi Yusuf dan Abu Hanifah. Mereka berpendapat bahwa dalam situasi seperti itu, satu-satunya cara untuk tetap berada di jalan lurus adalah kembaali kepada al-Qur'an. Berkaitan dengan upaya mencari kebenaran, harus merujuk pada QS. al-Hajj 54 bahwa kebenaran harus dicari dengan nalar (logika). Dari dasar ini kemudian lahir teori-teori kebenaran, seperti ilmu bayan, ilmu burhan, dan ilmu irfan. Abu Hanifahlah orang yang pertama merintis cara berpikir Ahlus Sunnah wal Jama'ah. Yakni cara berpikir dalam memahami agama yang meletakkan aspek tawasuth, tasamuh sebagai pijakan dalam mencari jalan tengah.

Sementara madzhab Aswaja secara resmi tersebar berkat Abu Hasan al-Asy'ari yang berhasil mengembangkan kerjasama konstruksif dengan pemerintahan Dinasti Abbasiah. Dari sini dapat ditarik kesimpulan bahwa Aswaja adalah suatu sistem atau cara yang kembali pada QS. al-Hajj 54, terlepas dari madzhabnya siapa, atau partainya apa. Abu Hanifah mendukung dan baiat terhadap Zaid bin Ali Zainal Abidin ketika berontak terhadap Dinasti Umayah. Ini berarti cara berpikir Abu Hanifah adalah Aswaja tetapi sikap politiknya Syiah. Imam Syafi'i juga mendukung sikap politik Syiah. Dengan demikian, Ahlus Sunnah wal Jama'ah, sebagai sebuah madzhab yang bisa dibaca secara jelas dokumen-dokumennya, sebenarnya tidak ada. Sikap jalan tengah dipakai karena bisa menjawab situasi saat itu, di mana rakyat sedang mengalami kebingungan (Said Aqiel Siradj, 2000: 28).

\section{NU dan Partai-Partai Islam}

Umat Islam sepakat membentuk wadah tunggal sebagai sarana perjuangan untuk menampung dan menyalurkan aspirasi politiknya. Wadah tersebut adalah Masyumi (Majelis Syuro Muslimin Indonesia). Kesepakatan ini diambil berdasarkan Kongres Umat Islam Indonesia (KUII) di Yogyakarta tanggal 7 - 8 Nopember 1945, di mana terdapat dua keputusan penting, yaitu: (1) Masyumi adalah satu-satunya partai politik Islam di Indonesia; (2) Partai Islam di luar Masyumi keberadaanya tidak diakui.

Keberadaan Masyumi sebagai wadah tunggal aspirasi politik umat Islam mengalami goncangan. Goncangan pertama terjadi pada 
bulan Juli 1947, yaitu dengan keluarnya unsur PSII dalam Masyumi. Goncangan yang paling dahsyat bagi Masyumi terjadi setelah NU mengikuti jejak PSII untuk meninggalkan Masyumi berdasarkan konggres NU di Palembang pada tanggal April 1952. Keputusan NU ini kemudian disusul oleh PERTI. Dari sinilah awal kiprah kepartaian NU yang dilakukan secara mandiri.

Deliar Noer (2000: 86) menilai bahwa dalam masa revolusi tidak terdapat indikasi yang memperlihatkan kebebasan NU dari Masyumi; dan ini sesuai dengan tekad tahun 1945 untuk mengakui Masyumi sebagai satu-satunya partai Islam di Indonesia. NU keluar dari Masyumi karena Masyumi yang berubah. Ada perubahan perumusan tentang Majelis Syuro dalam Anggaran Dasar/Anggaran Rumah Tangga. Berikut saya kutipkan pendapatnya:

"...Masjumi sejak konggresnya di Yogyakarta pada akhir tahun 1949...diubah demikian rupa, di mana Majelis Syuro yang merupakan tempat penting bagi para ulama dan pemimpinpemimpin di Islam menjadi anggotanya sudah tidak lagi dijadikan sebagai badan legislatif di samping DPP, melainkan hanya dijadikaan Badan Penasehat saja....Segala persoalan hanya dari jurusan politik saja dengan tidak lagi mengambil pedoman agama."

Dalam konggres itu juga ada di antara peserta yang mulai tidak memperlihatkan rasa hormatnya kepada ulama. Peserta ini juga menganggap lulusan sekolah Belanda lebih superior dari lulusan sekolah agama. Berikut saya kutipkan komentar KH Idham Chalid dari buku Deliar Noer (2000: 92):

"Ini terus terang saja waktu itu 5 menteri Masjumi, 4 sudah diambilnya. Departemen Agama masih diambilnya juga. Kalau orang mengatakan, NU pecah, karena kursi-meninggalkan Masjumi kata Masjumi. Baik, baik-karena kursi. Apa tidak pantas, tuan-tuan mengambil 4 kursi, satu yang dituntut oleh NU. Karena sekarang tuan-tuan tidak mau memberikan, tuantuan mau NU pecah karena kursi, sedangkan tuan-tuan telah punya, salah siapa. Kalau kita bersaudara mempunyai milik lima lantas tuan-tuan sudah ambil 4, kita cuma nuntut satu tidak diberi, kita pecah. Hujjahnya salah siapa-kalau memang benar karena kursi-saya mau tanya."

Untuk memahami perasaan NU, akan berguna rasanya bila kita merujuk pada dua kejadian yang sangat disesalkan oleh kalangan NU 
dan yang mencerminkan hubungan yang kurang serasi tadi. Seorang tokoh Masjumi, Mohammad Saleh, yang ketika itu menjadi Wali Kota Yogyakarta, berkata kepada konggres Masjumi bulan Desember 1949 bahwa karena politik merupakan bidang yang kompleks, tidak dapat ia ditangani oleh ulama. Seperi ditulis Deliar Noer (2000: 93-94), NU tersinggung dengan perkataan Mohammad Saleh berkata kira-kira,

"Ini politik adalah luas...Politik ini saudara-saudara, tidak bisa dibicarakan sambil memegang tasbih, jangan dikira scoop [scope]-nya politik ini hanya di sekeliling pondok dan pesantren saja. Dia luas menyebar ke seluruh dunia."

Kejadian lain dicatat pada rapat Dewan Partai Masyumi di Bogor pada tahun 1952. Menurut sumber NU, ketika K.H. Wahid Hasjim (NU) mengucapkan pidato dalam rapat, tidak seorang pun di luar kalangan NU yang mendengarkannya. Pada waktu itu K.H. Idham Chalid dari NU berdiri dan memprotes ketua, yang kebetulan adalah Mohammad Natsir, karena sikap dan tingkah yang hadir.

Faktor lain yang menyebabkan kurang mesranya hubungan antara Masjumi dan NU sesudah penyerahan kedaulatan ialah bergantinya ketua partai dari Sukiman ke Natsir. Dari masa Desember 1949 ini pimpinan Masjumi lebih dipercayakan pada angkatan di bawah generasi Sukiman, yaitu Natsir dan kawan-kawan.

Mengamati konflik antara NU dan Masyumi tidak dapat digeneralisasikan sebagai konflik antara pihak tradisionalis dengan pihak reformis. Memang kalau kita lihat para pengurus yang mendominasi Masyumi bukan lulusan pesantren, tetapi kita perlu melihat fakta sejarah lainnya bahwa Muhammadiyah juga menyatakan berhenti sebagai anggota istimewa (Nurcholish Madjid, 1997).

Kejadian-kejadian tersebut di atas memaksa NU keluar dari Masyumi pada tahun 1952. Walaupun tidak punya waktu cukup untuk sosialisasi namun dalam pemilu pertama tahun 1955, NU muncul sebagai partai ketiga terbesar, dengan menarik hampir 7 juta atau 18,4 $\%$ dari total suara nasional serta mendongkrak perwakilan di parlemen dari 8 orang ketika masih di Masyumi menjadi 45 orang. Kemenangan ini tentu saja melahirkan luapan kegembiraan bagi warga nahdliyyin, karena mereka merasa beratnya harapan dalam pertarungan tersebut, terlebih-lebih panitia pemenangan pemilu NU sendiri punya prediksi hanya akan memperoleh 20 - 25 kursi. Demikian juga halnya dengan susunan kabinet berdasarkan hasil PEMILU 1955, NU mampu mendudukkan 5 orangnya dalam kabinet, sama dengan Masyumi, sedang PSII 2 orang dan Perti 1 orang. 
Berdasarkan Dekrit Presiden tanggal 5 Juli 1959 Soekarno membubarkan parlemen hasil PEMILU 1955 karena dianggap gagal melakukan tugasnya. Masyumi menilai bahwa ikut serta dalam demokrasi terpimpin Soekarno yang otoriter merupakan penyimpangan terhadap ajaran Islam. Akan tetapi, Liga Muslimin (NU, PSII, dan Perti) menganggapnya sebagai sikap realistis dan pragmatis. Menurut Fachry Ali dan Bachtiar Efendy, keikutsertaan Liga Muslimin, terutama NU, hanya bersifat strategis dan bukan berarti idealismenya bergeser. Sebagai implikasi dari kerasnya penolakan Masyumi ini, maka pada tahun 1960 pemerintah rezim Soekarno memerintahkan agar Masyumi bubar.

Dalam situasi perbenturan ideologi nasionalis dengan Islam maka Soekarno mengurangi wakil Islam dalam parlemen (DPR-GR) yang diangkat sendiri oleh Soekarno. Jika dalam PEMILU 1955 kelompok Islam diwakili oleh sebanyak 115 orang, maka dalam DPRGR turun secara drastis menjadi 43 orang (36 NU, 5 PSII, 2 Perti) yang jika ditambah dengan anggota dari golongan dan lain-lain -sebanyak 24 orang-- jumlahnya menjadi 67 orang. Sementara itu, wakil golongan Nasionalis menjadi 94 orang dan komunis 81 orang, di mana jumlah anggota DPR-GR seluruhnya adalah 383 orang.

\section{NU dan Negara}

Kegagalan NU bersama dalam partai-partai Islam lain dalam usaha mewujudkan negara Islam melalui jalur konstitusional, tidak menjadikan NU bersifat oposisi terhadap pemerintah seperti yang dilakukan oleh Masyumi. Kesediaan NU bergabung dalam pemerintahan Demokrasi Terpimpin bentukan Presiden Soekarno tidak hanya berdasarkan pertimbangan politik, tetapi mempunyai landasan yang kuat berdasarkan pandangan keagamaan (fiqih). M. Ali Haidar telah menulis disertai yang menarik berkaitan dengan masalah ini, judulnya Nahdlatul Ulama dan Islam di Indonesia: Pendekatan Fiqih dalam Politik (M. Ali Haidar, 1998). Dia memberikan penjelasan yang meyakinkan bahwa 'Gagasan yang pertama kali ketika NU dibentuk bukanlah dari wawasan politik, melainkan dari wawasan sosial keagamaan. Meskipun demikian wawasan tersebut tidak lantas menjadikan NU mengabaikan soal-soal politik' (M. Ali Haidar, 1998: 2).

Memang kalau kita melihat sejarah NU kita dapat melihat keterlibatan NU dalam politik, baik secara langsung maupun tidak langsung. Sikap-sikap politik NU bukan hanya kebetulan belaka, 
sebab tahap-tahap pemikiran NU memiliki pijakan tradisi pemikiran fikih yang kuat. Sebagai organisasi Islam motivasi yang mempengaruhi setiap langkap NU ialah untuk mengamalkan dan melaksanakan ajaran Islam. Namun dalam mengantisipasi berbagai gejala sosial NU tidak bersikap mutlak-mutlakan. Kewajiban untuk mengamalkan ajaran Islam itu dipenuhi sebatas kemampuan dengan memperhatikan berbagai faktor lain. Jika kemampuan hanya menghasilkan sebagian saja, maka yang sebagian itu tidak ditinggalkan. Dasar kedua ialah dalam melaksanakan kewajiban diukur seberapa jauh dampak positif dan negatifnya. Jika ternyata mengakibatkan dampak negatif yang besar, langkah pertama yang dilakukan menghindari dampak negatif itu. Kewajiban tidak bisa dipaksakan jika ternyata dengan itu berakibat munculnya dampak negatif yang menimbulkan kerugian bagi diri atay orang lain. Jika ternyata dalam hal itu harus menghadapi pilihan, langkah yang diutamakan ialah yang paling kecil resiko negatifnya (akhaff aldarain) (M. Ali Haidar, 1998: 5-6).

Sudah tentu dengan tradisi pemikiran itu (Tradisi Ahlus Sunnah wal Jama'ah) tidak berarti NU selalu bersikap pesimis, menyerah sebelum bertanding. Dalam berbagai kesempatan NU juga pernah menampilkan sikap ofensif untuk melakukan jalb al-mashalih (melaksanakan kewajiban), tidak dalam kaitannya dengan aspek dlarurah (temporer) yang mungkin akan menimbulkan mafsadah (kerusakan). Peristiwa-peristiwa dalam sidang BPUPKI, Majelis Konstituante, maupun ketika NU mempelopori walk out dalam sidang MPR tentang P4, memperlihatkan sikap NU itu. Namun ketika hal itu dilihat tidak membawa hasil bahkan ternyata akan menimbulkan bahaya, NU segera merevisinya kembali dan menerima kesepakatan, meskipun mulanya menolak. Mengapa? Oleh karena motivasi utama yang mendasari langkah NU ialah adanya tertib sosial dan politik, sebab dengan tertib itulah kemungkinan bisa dikembangkan tertib agama. Tertib sosial politik menjadi prasyarat bagi terwujudnya tertib agama (nizham al-dunya syart li nizham al-dini).

\section{Penutup}

Perlu ditegaskan di sini bahwa berdirinya NU bukanlah antitesa bagi organisasi Islam yang telah ada, walaupun kemudian NU memang menjadi lawan bicara dalam pemikiran keagamaan. Casus belly (sebab langsung) kelahiran NU adalah sebagai respon langsung atas bangkitnya kekuasan Islam puritan Wahabi di Mekkah. 
Komite Khilafah yang dibentuk untuk mengirimkan wakil Indonesia ke Mekkah dianggap tidak dapat mewakili suara pihak pesantren, sehingga para ulama membentuk Komite Hijaz. Tujuan dibentuknya Komite Hijaz dalam sidang tanggal 31 Januari 1926 adalah untuk mengirimkan wakil ke Mekkah. Dalam sidang itu didirikan NU yang akan memberi mandat pada Komite Hijaz ini, ditetapkan para wakil yang akan dikirim ke Mekkah; dan kemudian dibubarkannya Komite Hijaz ini. Dengan demikian, tujuan didirikannya NU adalah untuk membela pemahaman agama yang berkembang di lingkungan pesantren dan sekaligus mensosialisasikan paham Ahlus Sunnah wal Jama'ah itu.

Aswaja adalah suatu sistem atau cara yang kembali pada QS alHajj 54 bahwa kebenaran harus dicari dengan nalar (logika). Abu Hanifah adalah orang yang merintis cara berpikir Aswaja. Yakni cara berpikir dalam memahami agama yang meletakkan aspek tawasuth, tasamuh sebagai pijakan dalam mencari jalan tengah, terlepas dari madzhabnya siapa, atau partainya apa. Abu Hanifah mendukung dan berbaiat pada pimpinan Syiah Zaid bin Ali Zainal Abidin yang memberontak terhadap Dinasti Umayah. Ini berarti cara berpikir Abu Hanifah adalah Aswaja, tapi sikap politiknya Syiah. Imam Syafi'i juga mendukung sikap politik Syiah. Dengan demikian, Aswaja sebagai sebuah madzhab yang bisa dibaca secara jelas dokumen-dokumennya, sebenarnya tidak ada. Aswaja bukanlah madzhab, tetapi manhaj alfikr (cara berpikir) yang bertumpu pada kebenaran dan menempuh cara-cara persuasif untuk menegakkannya, disamping menghindari cara-cara politik praktis.

Dengan berpijak pada ajaran Aswaja, NU berhasil mengembangkan suatu pemikiran agama yang dikemas dalam kerangka negara bangsa. Negara bangsa bukan suatu yang tabu dalam Islam, karena Kekhalifahan adalah hasil ijtihad para Sahabat Nabi yang tidak tabu terhadap kritik. Yang dipentingkan Islam bukan bentuk negara, tapi suatu negara sebagai suatu alat untuk menjamin adanya tertib sosial, suatu prasyarat bagi tegaknya agama. Tidak heran bila NU berhasil mengembangkan suatu pemikiran yang mendukung eksistensi Pancasila dalam kapasitasnya sebagai dasar negara Indonesia yang sebenar-benarnya. Dan pada tahun 19843, NU mempelopori mencabut Islam sebagai asas organisasi dan menggantinya dengan Pancasila. 


\section{Daftar Pustaka}

Deliar Noer. (2000). Partai Islam di Pentas Nasional. Bandung: Mizan.

Imam Baehaqi ed. (2000). Kontroversi Aswaja: Aula Perdebatan dan Interpretasi. Yogyakarta: LKiS.

M. Ali Haidar. (1998). Nahdlatul Ulama dan Islam di Indonesia: Pendekatan Fiqih dalam Politik, Jakarta: Gramedia.

Nurcholish Madjid, (1997), Tradisi Islam, Jakarta: Paramadina, hal

Said Aqiel Siradj, (2000), "Latar Kultural dan Politik Kelahiran Aswaja”, Dalam Imam Baehaqi ed., Kontroversi Aswaja: Aula Perdebatan dan Interpretasi, Yogyakarta: LKiS.

Sholahuddin Wahid, (2000), "Profil Nahdlatul Ulama", Wawancara dimuat dalam Majalah Tabligh. Vol.01/No.08/Maret 2003, dari http://groups.yahoo.com/group/ kmnu2000/.

\section{Biodata Penulis}

Saefur Rochmat, lahir di Kebumen 22 Nopember 1968. Menyelesaikan studi S1 Pendidikan Sejarah di UNY dan pra-S2 Ilmu Sejarah di UI Jakarta. Dia meraih gelar Master of International Relations dari Ritsumeikan University, Jepang. Sekarang menjadi dosen di Jurusan Sejarah FIS UNY. 